\title{
ANALISIS DAERAH PENANGKAPAN IKAN CAKALANG (Katsuwonus pelamis) DI SEKITAR BACAN DAN OBI, HALMAHERA SELATAN
}

\section{FISHING GROUND ANALYSIS OF CAKALANG (Katsuwonus pelamis) AROUND BACAN DAN OBI, SOUTHERN HALMAHERA DISTRICT}

\author{
Deni Sarianto \\ Prodi Perikanan Tangkap, Politeknik Kelautan dan Perikanan Dumai \\ Email: Denisarianto45@gmail.com
}

\begin{abstract}
ABSTRAK
Perairan Halmahera selatan telah lama menjadi pusat penangkapan ikan cakalang. Penentuan daerah penangkapan ikan dapat diperkirakan dari kondisi perairan yang merupakan habitat hidup. Klorofil-a dan suhu permukaan laut (SPL) merupakan parameter oseanografi yang penting untuk mengetahui keberadaan ikan cakalang dan mempermudah dalam menganalisis daerah penangkapan. Penelitian ini bertujuan untuk mengetahui ukuran ikan cakalang yang tertangkap dan menentukan sebaran klorofil-a serta SPL di perairan Bacan dan Obi. Hasil penelitian menunjukkan Hasil tangkapan cakalang di dominasi pada ikan ukuran layak tangkap pada golongan dua dan tiga dengan persentase $48 \%$ dan $23 \%$ sedangkan ikan tidak layak tangkap atau berukuran kurang dari $43 \mathrm{~cm}$ dengan presentase $28 \%$. Sebaran Klorofil-a di perairan Bacan dan Obi pada bulan Mei berkisar 0,163 - 0,652 $\mathrm{mg} / \mathrm{m}^{3}$ sedangkan klorofil-a pada bulan Juni berkisaran 0,142 - 0,575 mg/m ${ }^{3}$. Sebaran SPL pada bulan Mei berkisaran 27,65 - 32,31 ${ }^{\circ} \mathrm{C}$ sedangkan SPL pada bulan Juni berkisaran 27,65 - 31,58 ${ }^{\circ} \mathrm{C}$. Musim Peparlihan barat-timur dan musim timur tidak terlalu berpengaruh terhadap hasil tangkapan , tetapi daerah front memberikan pengaruh yang besar terhadap penbentukan Feeding graund serta memberi penghalang buat mingarsi ikan karna pergerakan air yang kuat.
\end{abstract}

Kata Kunci: Klorofil-a dan Suhu Permukaan Laut (SPL)

\section{PENDAHULUAN}

Ikan cakalang (Katsuwonus pelamis) merupakan salah satu komoditas perikanan unggulan bagi nelayan yang berbasis di PPP Bacan, Halmahera Selatan bahkan daerah Bacan dikenal sebagai penghasil ikan cakalang (Katsuwonus pelamis) terbesar di Maluku Utara. Ikan ini tidak hanya berperan strategis bagi sumber pendapatan nelayan setempat, tetapi juga sebagai pensuplai bahan baku industri pengolahan. Keberadaan perusahaan pengolahan tersebut sangat membantu para nelayan dalam menjual hasil tangkapannya. Nelayan pun menunjukkan kerjasama dengan pabrikpabrik tertentu, dengan membawa langsung hasil tangkapannya ke perusahaan untuk diolah. DKP (2017) melaporkan bahwa produk olahan ikan cakalang dari Halmahera Selatan telah didistribusikan ke berbagai daerah tujuan baik skala lokal maupun 
SEMAH : Journal Pengelolaan Sumberdaya Perairan VOL. 2 No. 3

Desember 2018

ekspor. Pasar lokal komoditi ini adalah Ternate, Manado, Surabaya, dan Jakarta, sedangkan pasar ekspor adalah Jepang, Amerika, dan sebagian Eropa.

Nelayan yang berbasis di PPP Bacan menangkap ikan cakalang tidak hanya terbatas di Perairan Bacan, tetapi juga di sekitar perairan Obi (Gambar 1). Hasil tangkapan nelayan di kawasan perairan Bacan dan Obi didominasi oleh cakalang, yaitu sekitar 81,85 \% (DKP 2017). Uktolseja (1989) menyatakan bahwa ikan cakalang di laut Maluku (Bacan, Ternate, Weda, Jailolo, Tobelo, Obi dan Sanana) dapat ditemukan sepanjang tahun, mulai dari ukuran kecil (juvenil) hingga ukuran dewasa.

Simbolon dan Girsang (2009) menyatakan ikan juvenil termasuk illegal size untuk ditangkap (tidak layak tangkap). Oleh karena itu, suatu perairan yang didominasi oleh ikan juvenil (illegal size) mengindikasikan bahwa perairan tersebut termasuk kategori daerah penangkapan yang tidak potensial. Hasil tangkapan yang didominasi oleh ikan juvenil akan membawa dampak negatif terhadap laju recruitment sumberdaya ikan, dan degradasi daerah penangkapan ikan. Kondisi ini dapat menyebabkan penurunan produksi ikan pelagis akibat tekanan daya penangkapan ikan tidak seimbang dengan daya pulih sebagaimana dilaporkan oleh Saputra et al (2011).

Selain ukuran panjang ikan, daerah penangkapan ikan potensial juga turut ditentukan oleh kelimpahan ikan. Simbolon (2009) menyatakan bahwa kelimpahan dan keberadaan ikan di suatu perairan dapat dipengaruhi oleh parameter oseanografi. Hal ini disebabkan karena ikan (termasuk cakalang) akan memilih habitat yang kondisi oseanografisnya sesuai dengan karakteristik biologis yang dikehendaki. Informasi tentang profil oseanografi ini relatif mudah diperoleh dewasa ini seiring dengan
http://ojs.umb-bungo.ac.id/index.php/SEMAHJPSP ISSN : 2580-0736

perkembangan teknologi penginderaan jarak jauh.

Suhu permukaan laut (SPL) dan konsentrasi klorofil-a berperan penting dalam menentukan distribusi hasil tangkapan cakalang di wilayah perairan Bacan dan wilayah perairan Obi. Hal ini mengindikasikan bahwa SPL dan klorofil-a dapat mempengaruhi dinamika daerah penangkapan ikan. Profil SPL dan klorofil-a yang sesuai dengan karakteristik biologis yang dikehendaki oleh ikan cakalang dapat berpengaruh positif terhadap proses terbentuknya daerah penangkapan ikan. Simbolon \& Limbong (2012) menyatakan bahwa SPL dan klorofil-a bisa jadi tidak berpengaruh secara langsung terhadap proses terbentuknya DPI pada waktu dan lokasi yang berbeda. Oleh karena itu, perlu dilakukan analisis mengenai pengaruh profil SPL dan klorofil-a terhadap hasil tangkapan cakalang.

Tujuan dari penelitian ini adalah: (1) menentukan komposisi jumlah dan ukuran ikan cakalang secara temporal dan spasial, (2) menentukan sebaran kandungan klorofila dan suhu permukaan laut di Perairan Bacan dan obi, Halmahera Selatan.

\section{METODELOGI PENELITIAN}

\section{Waktu dan Tempat Penelitian}

Pengumpulan data tangkapan ikan cakalang dilakukan pada bulan Mei sampai dengan Juni 2018 di Perairan Bacan dan Obi, dimana nelayan yang berbasis di PPP Bacan menangkap ikan cakalang (Gambar 1). Data SPL dan klorofil-a diunduh dari internet (http://oceancolor.gsfc.nasa.gov) pada bulan Mei dan Juni 2018 
SEMAH : Journal Pengelolaan Sumberdaya Perairan VOL. 2 No. 3

Desember 2018

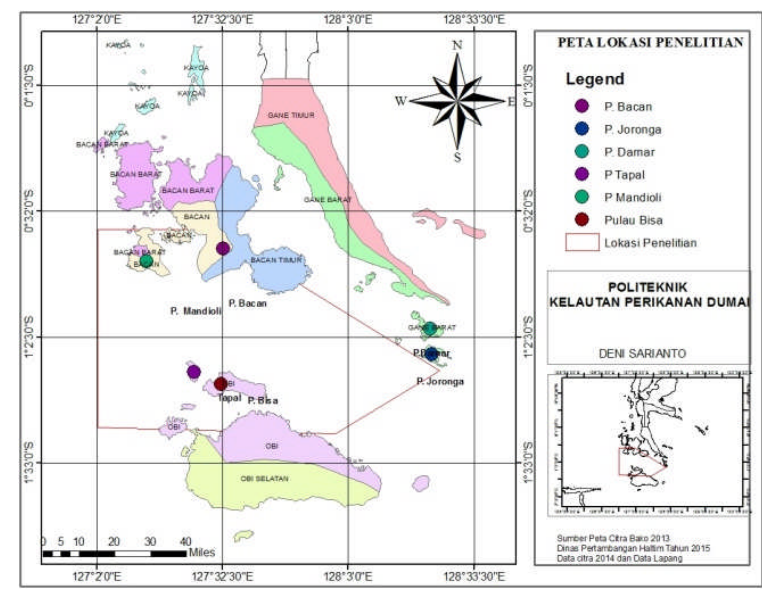

Gambar 1 Peta Lokasi Penelitian Kabupaten Halmahera Selatan

\section{Pengumpulan Data}

Metode yang digunakan dalam penelitian ini adalah metode survei, dengan mengamati 6 unit pole and line sebagai sampel yang menangkap ikan cakalang. Data yang dikumpulkan dari kegiatan penangkapan ikan meliputi waktu dan lokasi atau posisi penangkapan ikan, jumlah dan ukuran ikan yang tertangkap. Jumlah tangkapan ikan cakalang dicatat pada setiap lokasi penangkapan. Sampel ikan diambil secara acak pada setiap posisi penangkapan, untuk selanjutnya diukur panjangnya (total lenght).

Data klorofil-a dan suhu permukaan laut (SPL) di lokasi penelitian diperoleh dengan cara mengunduh citra SPL dan klorofil-a yang dideteksi satelit Terra/Aqua (MODIS), dan citra ini tersedia di internet (http://oceancolor.gsfc.nasa.gov.).Citra yang dipilih merupakan data harian SPL dan klorofil-a level 3 pada waktu dan tempat yang bersamaan dengan kegiatan operasi penangkpan ikan.

\section{Analisis Data}

\section{Komposisi Hasil Tangkapan}

Hasil tangkapan dianalisis untuk mengetahui produktivitas atau catch per unit effort (CPUE) secara temporal dan spasial. CPUE ini dihitung dengan formula berikut:
http://ojs.umb-bungo.ac.id/index.php/SEMAHJPSP ISSN : 2580-0736

$$
C P U E=\frac{\mathrm{C}}{\mathrm{f}}
$$

Keterangan:

$$
\begin{array}{ll}
\mathrm{C} & \text { : Hasil tangkapan }(\mathrm{kg}) \\
\mathrm{f} & \text { : Jumlah hari operasi (trip) }
\end{array}
$$

Data ukuran ikan dikategorikan menjadi dua kelompok sesuai dengan kategori yang disampaikan oleh Simbolon dan Limbong (2013) yaitu: (1) ukuran layak tangkap, dan (2) ukuran tidak layak tangkap. Presentase jumlah masing-masing kelompok ukuran tersebut dihitung dengan formula

$$
=-
$$

Keterangan:

$\mathrm{P}:$ presentase setiap kelompok ukuran $(\%)$

ni: jumlah ikan (ekor) pada kelompok ukuran ke-i $(\mathrm{i}=1, \ldots, 2)$

$\mathrm{N}$ : total ikan sampel yag diukur (ekor)

\section{Sebaran SPL dan Klorofil-a}

Data sebaran SPL dan klorofil-a hasil deteksi satelit Terra/Aqua MODIS diolah dengan software SeaDAS 7.5 level 3 hingga didapat data dalam bentuk American Standard Code for Information Interchange (ascii). Data ascii kemudian diolah dengan excel dan disajikan dalam bentuk grafik. Penggunaan level 3 dalam mengolah data karena data citra pada level tersebut sudah diolah dan sudah dikoreksi secara radiometrik dan geometrik.

Suhu permukaan air laut didapatkan dengan menggunakan algoritma Miami Pathfinder SST (MPFSST) (Minnett et al. 2002) dengan rumus:

$$
\begin{gathered}
\text { modis }_{S S t}=c_{1}+c_{2} * T_{31}+c_{3} * T_{3132}+c_{4} * \\
\left.(\sec ()-1) * T_{3132}\right)
\end{gathered}
$$


SEMAH : Journal Pengelolaan Sumberdaya Perairan VOL. 2 No. 3

Desember 2018

Keterangan:

$\mathrm{T}_{31}$ : adalah brightness temperature (BT) pada band 31 (pada AVHRR kanal 4)

$T_{3132}$ : adalah pebedaan BT pada band 31-band 32 (pada AVVHRR kanal 4 dan 5)

$c_{1}, c_{2}, c_{3}, c_{3}$ : adalah koefisien band 31 dan 32, adalah sudut zenith satelit.

Sebaran klorofil-a didapatkan dengan menggunakan formulasi algoritma OC $3 \mathrm{M}$ (ocean chlorophyll three-band algoritma for MODIS), dengan rumus:

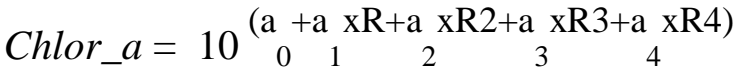

$$
\begin{aligned}
& \text { ao }=0.2830, \mathrm{a}_{1}=-2.753, \mathrm{a}_{2}=1.457 \text {, } \\
& \mathrm{a}_{3}=0.659 \text { dan } \mathrm{a}_{4}=-1.403
\end{aligned}
$$

Yang mana:

$$
R=\log 10\left(\frac{\left.R_{r s} 403\right\rangle R_{r s} 488}{R_{r s} 551}\right)
$$

Keterangan: $\mathrm{R}_{\mathrm{rs}}$ adalah remote sensing reflectance

Variabilitas atau keragaman data merupakan salah satu teknik yang digunakan untuk menjelaskan homogenitas data SPL dan klorofil-a.Variabilitas atau keragaman data dapat dihitung menggunakan rumus sebagai berikut (Sugiyono 2007):

$$
\begin{aligned}
s^{2}=\frac{\sum_{i=1}^{n}\left(x_{i}-\bar{x}\right)^{2}}{n-1} & \\
s & =\sqrt{s^{2}} \\
K v & =\frac{s}{x} \cdot 100 \%
\end{aligned}
$$

Keterangan :

$\begin{array}{ll}s^{2} & : \text { ragam contoh } \\ s & : \text { simpangan baku } \\ x_{i} & : \text { data ke-i } \\ x & : \text { rata-rata } \\ K v & : \text { koefisien variasi }\end{array}$

http://ojs.umb-bungo.ac.id/index.php/SEMAHJPSP ISSN : 2580-0736

\section{Hubungan Hasil Tangkapan dengan SPL dan Klorofil-a}

Untuk menentukan hubungan antara klorofil-a dengan hasil tangkapan dan antara suhu permukaan laut dengan hasil tangkapan maka dilakukan analisis deskriptif dengan teknik overlay antara SPL dengan CPUE dan klorofil-a dengan CPUE.

\section{HASIL DAN PEMBAHASAN}

\section{Produksi cakalang yang didaratkan di PPP Bacan}

Jumlah total tangkapan ikan cakalang yang didaratkan di PPP Bacan pada saat penelitian adalah 214,19 ton bulan Mei dan 150,911 ton bulan Juni. Tangkapan tersebut berasal dari 39 armada di bulan Mei dan 29 armada di bulan Juni yang beroperasi di perairan Bacan dan Obi (Gambar 2). Sebaran jumlah produksi dan produktivitas tangkapan cakalang di setiap armada yang mendaratkan ikan di PPP Panamboang.

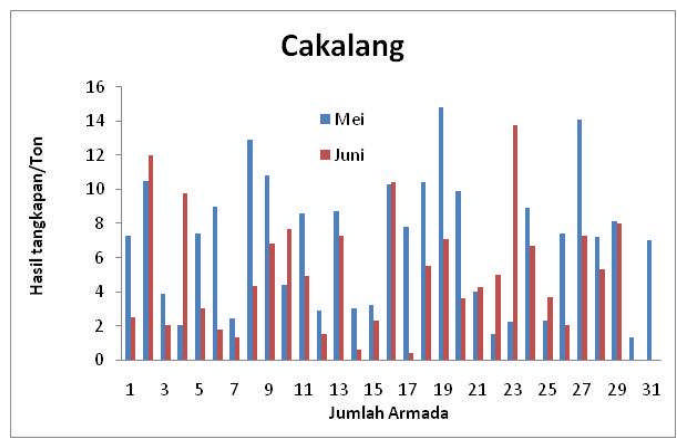

Gambar 2 Sebaran jumlah produksi dan produktivitas tangkapan cakalang

Bulan Mei dan Juni 2018

Operasi penangkapan ikan cakalang di Obi tidak hanya dilakukan oleh nelayan yang berasal dari Bacan, Halmahera Selatan tetapi juga dilakukan oleh nelayan yang berasal dari Ternate, dan Bitung . Pemanfaatan ikan cakalang di Obi terkadang menimbulkan konlik karena nelayan dari Bacan, Ternate, dan Bitung saling mengklaim bahwa Rumpon di perairan 
SEMAH : Journal Pengelolaan Sumberdaya Perairan VOL. 2 No. 3

Desember 2018

tersebut merupakan milik mereka. Oleh karena itu, para stakeholders terkait perlu menyusun zonasi pelepasan rumpon yang lebih jelas untuk digunakan sebagai acuan dalam sharing pemanfaatan DPI di Bacan dan Obi tersebut.

Produktivitas atau catch per unit effort (CPUE) rata-rata selama penelitian adalah 6,909 ton per trip bulan Mei dan 5,203 ton per trip bulan Juni. Hal ini berarti bahwa DPI Bacan dan Obi, dapat dikategorikan sebagai DPI potensial berdasarkan pendekatan produktivitasnya.

\section{Ukuran panjang ikan cakalang}

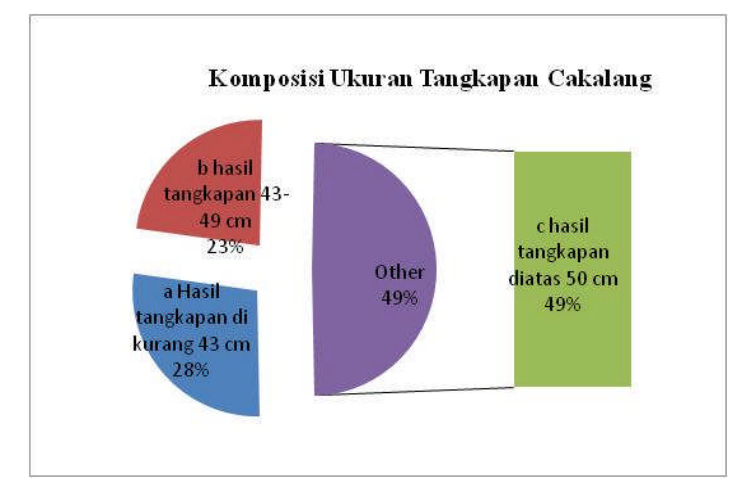

Gambar 3 Komposisi jumlah tangkapan berdasarkan kelompok ukuran ikan cakalang yang didaratkan di PPP Bacan,

$$
\text { Mei - Juni } 2018
$$

Ukuran ikan cakalang yang tertangkap selama penelitian sangat beragam mulai dari ukuran kecil hingga besar (Gambar 3). Ikan cakalang di kelompokan dalan 3 ukuran: kelompok pertama ikan cakalang berukuran kurang dari $43 \mathrm{~cm}$, kelompok kedua ikan cakang ber ukuran antara 43-49 $\mathrm{cm}$, dan kelompok ke tiga cakalang berukuran diatas $50 \mathrm{~cm}$. Ikan cakalang yang dominan tertangkap dalam penelitian bulan Mei - Juni 2018 adalah kelompok ketiga, yaitu lebih besar dari $50 \mathrm{~cm}$ dari total sampel 800 ekor. Urutan berikutnya adalah kelompok pertama 28\%, kelompok kedua 23\%. Jika kelompok cakalang kecil yang berukuran lebih kecil dari $43 \mathrm{~cm}$ per individu diasumsikan sebagai illegal size
http://ojs.umb-bungo.ac.id/index.php/SEMAHJPSP ISSN : 2580-0736

yang tidak layak tangkap dan dua kelompok lainnya dianggap sebagai legal size, maka cakalang yang masuk dalam kategori layak tangkap selama penelitian $72 \%$. Hal ini berararti bahwa tangkapan cakalang didominasi oleh kelompok ikan layak tangkap, yaitu $72 \%$ dimana terdiri dari $49 \%$ katagori industri/ekspor dan 23 persen katagori lokal. Karman et al (2013) menyatakan bahwa ikan cakalang yang tertangkap di perairan Maluku Utara pertama kali matang gonat pada panjang 43 cm. Jatmiko et al (2015) menyatakan panjang ikan cakalang pertama kali matang gonat di perairan Aceh adalah 42,9 cm.

\section{Klorofil-a di Obi, dan hubungannya dengan tangkapan cakalang}

Kandungan klorofil-a yang terdapat pada Obi berfluktuatif setiap harinya (Gambar 4 dan 5). Kandungan klorofil-a di perairan Obi berkisar antara 0,1633 $0,65287 \mathrm{mg} / \mathrm{m}^{3}$, dan kandungan klorofil-a rata-rata sebesar $0,9751 \mathrm{mg} / \mathrm{m}^{3}$ pada bulan Mei. Kandungan klorofil-a di bulan Juni berkisar antara $0,1420-0,5755 \mathrm{mg} / \mathrm{m}^{3}$, dan kandungan klorofil-a rata-rata sebesar $0.2947 \mathrm{mg} / \mathrm{m}^{3}$. Kandungan klorofil-a harian mengalami perubahan, klorofil-a cenderung tinggi pada awal bulan Mei pada tanggal 3 . untuk bulan Juni klorofil tertinggi pada 5, 20, dan 22. Citra klorofil-a harian tidak diperoleh secara kontinu karena citra satelit Aqua/Modis terhalang oleh awan sehingga tidak terdeteksi adanya kandungan klorofil-a di Obi pada tanggal-tanggal tertentu.

Penelitian Khasanah et al (2013) menunjukkan bahwa kelimpahan plankton yang dievaluasi berdasarkan kandungan klorofil-a di perairan berfluktuasi tergantung pada perubahan musim. Variasi konsentrasi klorofil-a memberikan pengaruh langsung maupun tidak langsung terhadap produksi ikan cakalang di Bacan dan Obi. 
SEMAH : Journal Pengelolaan Sumberdaya Perairan VOL. 2 No. 3

Desember 2018

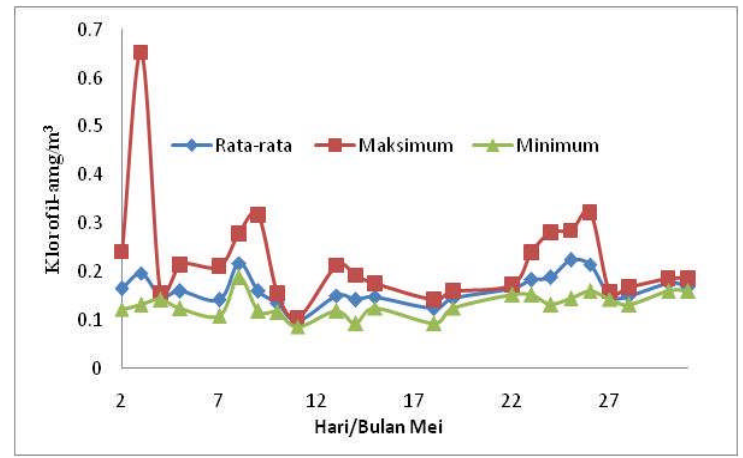

Gambar 4 kandungan klorofil-a data harian bulan Mei 2018

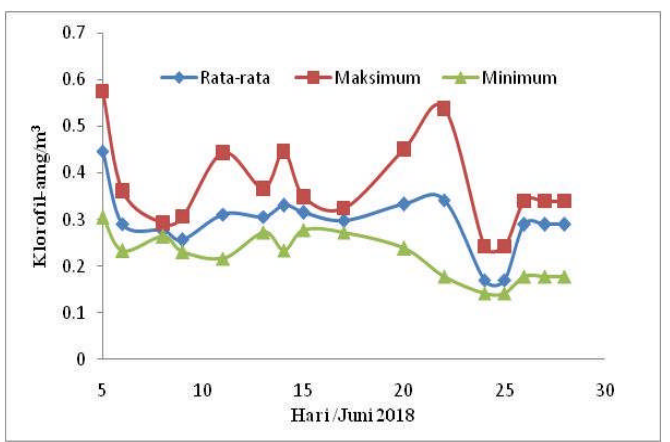

Gambar 5 kandungan klorofil-a data harian bulan Juni 2018

Penelitian Khasanah et al (2013) menunjukkan bahwa kelimpahan plankton yang dievaluasi berdasarkan kandungan klorofil-a di perairan berfluktuasi tergantung pada perubahan musim. Variasi konsentrasi klorofil-a memberikan pengaruh langsung maupun tidak langsung terhadap produksi ikan cakalang di Bacan dan Obi.

Hubungan antara klorofil-a dengan produksi ikan cakalang yang didaratkan di TPI Bacan selama 1 bulan (Mei - Juni 2018) disajikan pada Gambar 6 dan 7. Secara keseluruhan tren fluktuasi konsentrasi klorofil-a dan produksi cakalang hampir sama, namun puncak peningkatan klorofil-a dan cakalang tidak terjadi secara bersamaan.

Keberadaan klorofil-a mempengaruhi jumlah hasil tangkapan nelayan PPP Bacan (Gambar 6dan 7). Saat konsentrasi klorofil-a rendah pada tanggal 4, 7, dan 28 Mei 2018 untuk bulan Juni klorofil terendah ada pada
http://ojs.umb-bungo.ac.id/index.php/SEMAHJPSP ISSN : 2580-0736

tanggal 6, dan 25 Juli 2018, hasil tangkapan ikan cakalang di PPP Bacan juga menunjukkan nilai yang rendah juga.

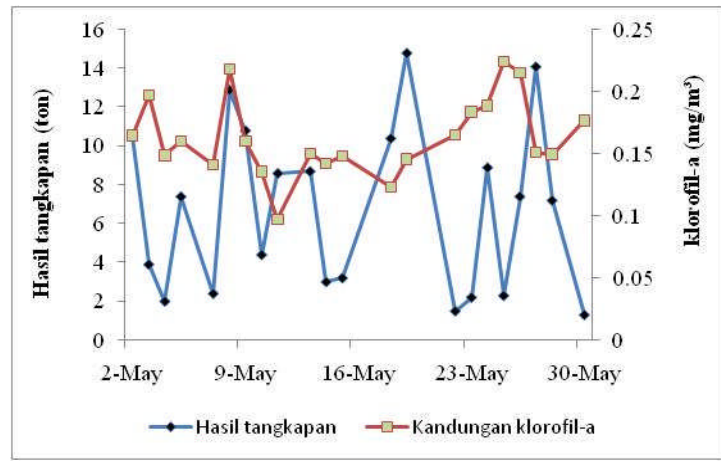

Gambar 6 Hubungan kandungan klorofil-a dengan hasil tangkapan di PPP Bacan secara temporal Mei 2018

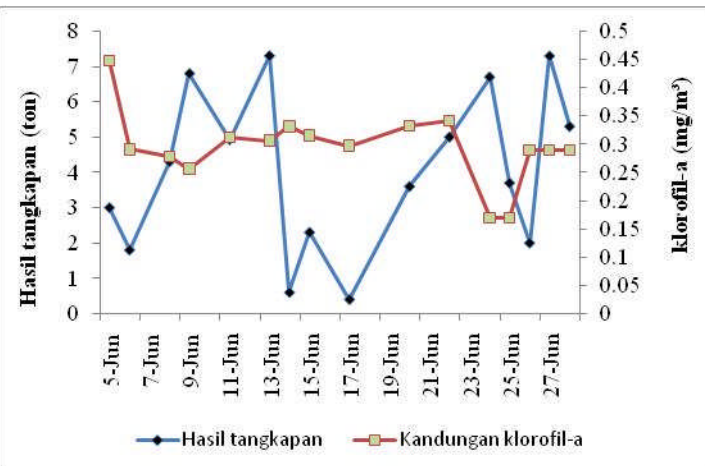

Gambar 7 Hubungan kandungan klorofil-a dengan hasil tangkapan di PPP Bacan secara temporal bulan Juni 2018

Konsentrasi klorofil-a mengalami peningkatan, dan volume hasil tangkapan ikan cakalang juga mengalami peningkatan. Akan tetapi peningkatan klorofil-a pada tanggal 3, 25, dan 30 Mei tidak dikuti oleh peningkatan jumlah hasil tangkapan. Pada bulan Juni terjadi pada tanggal 14, dan 26 terjadi hal yang sama juga dimana peningkatan hasil tangkapan tidak di ikuti dengan peningkatan klorofil-a. Hal ini menunjukkan bahwa peningkatan jumlah plankton di perairan tidak selalu memberikan dampak terhadap peningakatan jumlah tangkapan secara langsung. Konisi ini terjadi akibat adanya time lag didalam 
SEMAH : Journal Pengelolaan Sumberdaya Perairan VOL. 2 No. 3

Desember 2018

rantai makanan. Selain faktor makanan, faktor lingkungan juga sangat berpengaruh terhadap penyebaran ikan. Ikan cakalang umumnya menyukai perairan dengan arus yang lemah (Simbolon \& Girsang 2009).

Hubungan antara peningkatan konsentrasi klorofil-a dan produksi cakalang di Perairan Bacan dan Obi terkait dengan melimpahnya plankton sebagai sumber makanan ikan cakalang. Pada musim peralihan barat-timur dan musim timur, perairan Obi merupakan daeah front. Kondisi ini berpengaruh terbentuknya feeding graund bagi ikan. selain itu pertemuan dua massa air merupakan penghalang migrasi ikan karena pergerakan air yang cepat dan ombak yang besar, sehingga daerah front merupakan daerah yang cocok untuk penyebaran jenis-jenis ikan tuna. Unsur hara yang ikut terangkut ke lapisan permukaan dan selanjutnya berperan penting untuk pertumbuhan plankton. Kelimpahan plankton yang tinggi ini menyebabkan ikan cakalang meningkat karena ikan ini termasuk kelompok planktonfeeder.

\section{Sebaran Suhu Permukaan Laut di Obi, dan Hubungannya dengan Tangkapan Cakalang}

Ikan cakalang yang didaratkan di PPP Bacan $98 \%$ ditangkap dengan pole and line pada pagi hari dan sore hari. SPL pada siangi hari di perairan Obi bulan Mei 2018 berkisar antara $27,65-32,31^{\circ} \mathrm{C}$ dengan suhu rata-rata sebesar $29,90^{\circ} \mathrm{C}$ (Gambar 8 dan 9). Bulan juni 2018 SPL di obi berkisaran 27,65 - 31,58 dengan suhu rata-rata $29,62^{\circ} \mathrm{C}$. Hasil penelitian ini sesuai dengan penelitian Ridha et al. (2013) yang menyatakan bahwa suhu perairan Obi pada musim barat berkisar antara $27-30^{\circ} \mathrm{C}$. Hasil penelitian ini juga senada dengan pendapat Nontji (2005), Suhu air di perairan Indonesia umumnya berkisar antara $28-31^{\circ} \mathrm{C}$.
http://ojs.umb-bungo.ac.id/index.php/SEMAHJPSP

ISSN : 2580-0736

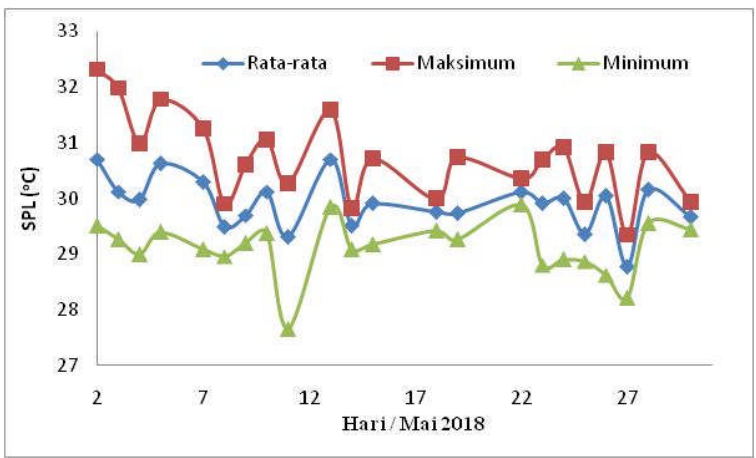

Gambar 8 Sebaran SPL di perairan Obi pada bulan Mei dan Juni 2018

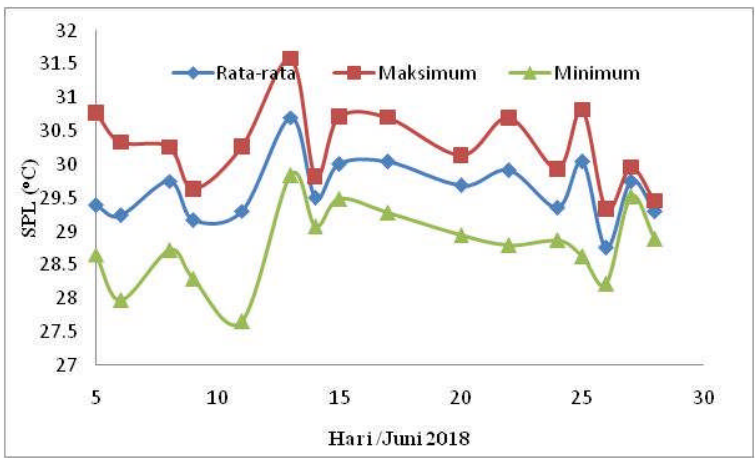

Gambar 9 Sebaran SPL di perairan Obi pada bulan Februari-Maret 2015

Suhu terendah terjadi pada tanggal 11 Mei dan 11 Juni yaitu sebesar $27,65^{\circ} \mathrm{C}$. Kenaikan suhu yang sangat drastis terjadi pada tanggal 2 Mei dan 30 juni, Hal tersebut diduga karena pada tanggal 14-15 Februari terjadinya curah hujan yang cukup tinggi dan penutupan awan yang tebal menyebabkan intensitas radiasi maahari sangat sedikit sehingga SPL menjadi dingin (Simbolon 2009).

Sebaran SPL dan produksi ikan cakalang yang didaratkan di TPI Bacan selama bulan Mei dan Juni 2018 disajikan pada Gambar 10 dan 11. Ikan cakalang tertangkap pada kisaran suhu antara $27,65^{\circ}$ $32,33^{\circ} \mathrm{C}$, dengan suhu rata-rata $29,0^{\circ} \mathrm{C}$. Hasil tangkapan tertinggi terjadi pada tanggal 14 mei dan 28 Mei dengan hasil tangkapan sebesar 14,80 ton dan 14,1 ton dengan suhu permukaan laut sebesar $29,7^{\circ} \mathrm{C}$ dan $29,7^{\circ} \mathrm{C}$. Hasil penelitian ini sesuai dengan penelitian Angraeni (2016) kepadatan cakalang 
SEMAH : Journal Pengelolaan Sumberdaya Perairan VOL. 2 No. 3

Desember 2018

tertinggi terdapat pada perairan yang memiliki suhu berkisar $29-31,4^{\circ} \mathrm{C}$. Jufri et al (2014) menyatakan bahwa ikan cakalang memiliki kecenderungan kelimpahan pada suhu optimum antara $29,9-31^{\circ} \mathrm{C}$. Hasil berbeda dengan penelitian yang dilakukan oleh Simbolon (2010) bahwa ikan cakalang menyukai perubahan suhu perairan dengan suhu yaitu $22^{\circ}-31^{\circ} \mathrm{C}$. Hasil tangkapan terendah terjadi pada tanggal 30 Mei 2018 dan 17 Juni 2018 dengan suhu permukaan laut sebesar $29,66^{\circ} \mathrm{C}$, dan $30,04^{\circ} \mathrm{C}$. Hasil tangkapan yang rendah diduga karena telah masuk puncak terang bulan.

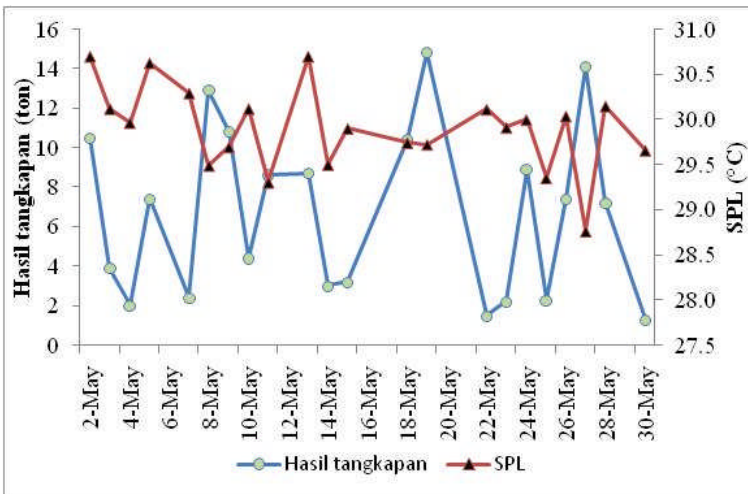

Gambar 109 Hubungan hasil tangkapan cakalang dengan SPL harian pada bulan

Mei 2018 secara temporal

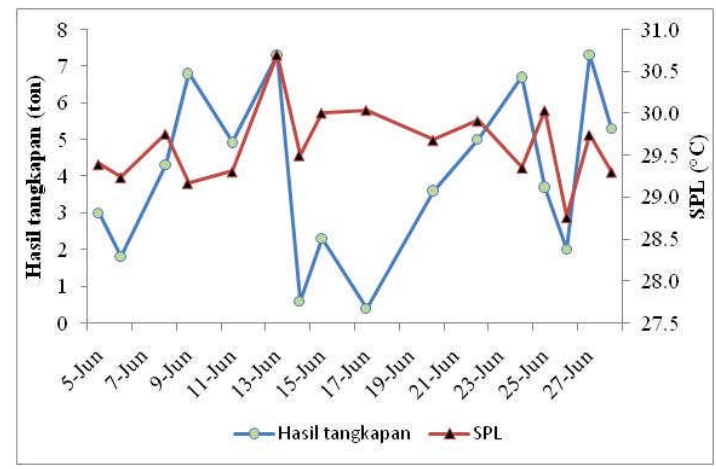

Gambar 119 Hubungan hasil tangkapan cakalang dengan SPL harian pada bulan Juni 2015 secara temporal

Simbolon (2008) menytakan bahwa pengaruh suhu perairan terhadap sebaran ikan sangat tergantung pada variabilitas suhu itu sendiri. Jika sebaran suhu perairan
http://ojs.umb-bungo.ac.id/index.php/SEMAHJPSP ISSN : 2580-0736

masih berada pada kisaran nilai yang dapat ditoleransi ikan, maka suhu perairan umumnya tidak berpengaruh secara nyata terhadap keberadaan ikan. Kondisi inilah yang diduga terjadi pada penelitian ini sehingga SPL tidak berpengaruh nyata terhadap hasil tangkapan ikan cakalang.

Seluruh daerah penangkapan cakalang menunjukkan suhu optimum untuk penangkapan cakalang. Uji statistik menujukkan bahwa SPL tidak berpengaruh terhadap hasil tangkapan secara spasial karena seluruh daerah penangkapan ikan memiliki sebaran SPL homogen dan berada pada kisaran SPL optimum untuk penangkapan cakalang.

\section{KESIMPULAN DAN SARAN}

\section{Kesimpulan}

Kesimpulan yang diperoleh dari penelitian ini adalah:

a) Ikan Cakalang yang tertangkap di perairan Bacan dan Obi sebanyak 214,19 ton, dan 150,911 ton, dengan CPUE 6,909 ton per trip dan 5,203 ton per trip . Ukuran ikan yang tertangkap didominasi ukuran layak tangkap yaitu sebanyak 395 ekor (48\%) di tambang kelompok ke dua sebanya 185 ekor $(23 \%)$. Sedangkan yang tidak layak tangkap adalah sebesar 220 (28\%);

b) Kandungan klorofil-a di Perairan Bacan dan Obi pada bulan Mei dan Juni 2018 berpengaruh terhadap komposisi jumlah hasil tangkapan ikan cakalang di PPP Panambuang, sedangkan SPL tidak berpengaruh terhadap jumlah hasil tangkapan ikan cakalang;

c) Daerah penangkapan ikan cakalang potensial di Perairan Bacan dan Obi pada bulan Mei dan Juni 2018 hanya terdapat di Perairan Tanjung Gurangg ( Nandopolo, Pasir Putih,, Tapal, Pulau Bisa). 
SEMAH : Journal Pengelolaan Sumberdaya Perairan VOL. 2 No. 3

Desember 2018

\section{Saran}

a) Penelitian lanjutan terkait dengan hasil tangkapan cakalang pada seluruh musim penangkapan perlu dilakukan agar dinamika daerah penangkapan cakalang dapat diamati pada musim yang berbeda;

b) Jumlah alat tangkap dan ukuran mata jaring pole and lineyang beroperasi di Perairan Bacan dan Obi perlu diatur dalam rangka mewujurkan perikanan tangkap yang ramah lingkungan dan berkelanjutan.

\section{DAFTAR PUSTAKA}

Angraeni, A., Rezkyanti, N. I., Safruddin, S., \& Zainuddin, M. (2016). Analisis Spasial dan Temporal Hasil Tangkapan Ikan Cakalang (Katsuwonus pelamis) dan thermal front pada musim peralihan di perairan Teluk Bone. Jurnal IPTEKS Pemanfaatan Sumberdaya Perikanan, 1(1).

Dinas Kelautan Perikanan. 2017. Laporan Tahunan Tahun 2017. Dinas Perikanan Daerah Tingkat II Kabupaten Halmahera Selatan, Halmahera Selatan.

Jatmiko, I., Hartaty, H., \& Bahtiar, A. (2015). Biologi reproduksi ikan Cakalang (Katsuwonus pelamis) di Samudera Hindia Bagian Timur. BAWAL Widya Riset Perikanan Tangkap, 7(2), 87-94.

Jessup, A. T., Fogelberg, R. A., \& Minnett, P. (2002, September). Autonomous shipboard infrared radiometer system for in situ validation of satellite SST. In Earth Observing Systems VII (Vol. 4814, pp. 222-230). International Society for Optics and Photonics.
http://ojs.umb-bungo.ac.id/index.php/SEMAHJPSP ISSN : 2580-0736

Jufri Adi; Amran M. Anshar; Zainuddin Mukti. 2016. Karakteristik daerah penangkapan ikan cakalang pada musim barat di perairan Teluk Bone. Jurnal IPTEKS Pemanfaatan Sumberdaya Perikanan, 1.1.

Karman, A., Martasuganda, S., Sondita, M. F. A., \& Baskoro, M. S. (2013). Capture fishery biology of skipjack in western and southern water of North Maluku Province. International Journal of Science, 432-448.

Khasanah, R. I., Sartimbul, A., Herawati, E. Y., Veteran, J., \& Veteran, J. (2013). Kelimpahan dan keanekaragaman plankton di perairan Selat Bali. Ilmu Kelautan, 18(4), 193-202.

Nontji A. 2005. Laut Nusantara (ed.rev.cet.4). Jakarta (ID): Djambatan.

Ocean Color Web. http://www.oceancolor.gsfc.nasa.gov [diunduh: Mei sampai Juni [2018]

Simbolon D. 2008.Pendugaan Daerah Penangkapan Ikan Tongkol Berdasarkan Pendekatan Suhu Permukaan Laut Deteksi Satelit dan Hasil Tangkapan di Perairan Teluk Palabuhanratu. Jurnal Litbangda NTT 4:23-30.

Simbolon D. 2009. Eksplorasi Daerah Penangkapan Ikan Cakalang melalui Analisis Suhu Permukaan Laut dan Hasil Tangkapan di Perairan Teluk Palabuhanratu. Jurnal Mangrove dan Pesisir X. 1: 42-49. ISSN: 1411-0679.

Simbolon, D. (2010). Eksplorasi daerah penangkapan ikan cakalang melalui analisis suhu permukaan laut dan hasil tangkapan di perairan Teluk Palabuhanratu. Jurnal Mangrove dan Pesisir, 1(2), 42-49. 
SEMAH : Journal Pengelolaan Sumberdaya Perairan

VOL. 2 No. 3

Desember 2018

Simbolon D. 2011. Bioekologi dan Daerah Penangkapan Ikan. Bogor (ID): Departemen Pemanfaatan Sumberdaya Perikanan FPIK IPB.

Simbolon D, HS. Girsang. 2009. Hubungan antara Kandungan Klorofil-a dengan Hasil Tangkapan Tongkol di Daerah Penangkapan Ikan Perairan Pelabuhanratu. Jurnal Penelitian Perikanan Indonesia. 15(4):297-305.

Simbolon D., M. Limbong. 2012. Exploration of skipjack fishing ground through sea surface temperature and catches composition analyzes in Palabuhanratu Bay waters. Journal of Coastal Development Research Institute, UNDIP \& ISOI. Vol 12. No 2: 225-233. ISSN 1410-5217.

Sugiyono. 2007. Metode Penelitian Pendidikan Kuantitatif, Kualitatif dan R \& D. Bandung: ALFABETA.

Uktolseja, J. B. C. (1989). An analysis of catch and effort during the first year development of Nucleus Estate for small holders rumpon system in Labuha, North Molucca, 19871988. Jurnal Penelitian Perikanan Laut (Indonesia).

Laut (Indonesia). 